\title{
The Argument and Semantic Structures of Japanese Verb Give
}

\author{
I Gede Oeinada \\ Udayana University, Denpasar, Indonesia \\ Ni Luh Sutjiati Beratha \\ Udayana University, Denpasar, Indonesia \\ I Nengah Sudipa \\ Udayana University, Denpasar, Indonesia \\ Made Sri Satyawati \\ Udayana University, Denpasar, Indonesia
}

\begin{abstract}
This study examines four Japanese synonymous verbs that have the same equivalent in English, namely GIVE. These four Japanese synonymous verbs are ageru, kureru, kizou suru, and kifu suru. This study used a qualitative descriptive method. Example sentences for the data were taken from Balance Corpus of Contemporary Written Japanese corpus data. The theories applied in this study are argument structure theory and Natural Semantic Metalanguage theory. Based on the analysis, there were selectional restrictions found in the argument structure of these synonymous verbs that can be used to distinguish one verb from another. In addition, these synonymous verbs, although there are some overlapping meaning components, have distinctive meaning components belonging to each verb. Therefore, it can be said that these synonymous verbs cannot fully replace each other in all contexts.
\end{abstract}

Index Terms — natural semantic metalanguage, explication, semantic roles, synonymy

\section{INTRODUCTION}

According to a press release from the Japan Foundation (2019), in 2018, Indonesia has the second largest number of Japanese learners in the world. This survey is conducted every three years. Typologically, these two languages belong to distinct groups. Indonesian is in the same group with English that has the SVO sentence structure, while Japanese has the SOV sentence structure (Horie, 2018). Not only the sentence structure but also the phrase structure is different in Indonesian and Japanese. In Indonesian, for example, the phrase red car is expressed by mobil merah (mobil 'car' and merah 'red') while in Japanese, it is expressed by akai kuruma (akai 'red' and kuruma 'car'). Besides these syntactical differences, Indonesian learners of Japanese also have difficulty in differentiating the right usage of synonymous verbs.

Previous studies on synonymous Japanese verbs have been conducted by several researchers such as Gumbira (2013), Zarifa, Herniwati, and Sutjiati (2017), Shiba and Cho (2017). These three studies on Japanese synonymous verbs used linguistic corpus as a tool for the analysis. By using linguistic corpus, the token frequency can be found, and the collocation of these verbs can be understood. However, it is difficult to grasp the meaning components without doing both the argument structure and semantic structure analysis. Semantic structure analysis can be done by applying the Natural Semantic Metalanguage (NSM) theory. Some studies on synonymous Japanese words that use NSM theory can be seen in Otomo and Torii (2005) as well as in Hasada (2008). Otomo and Torii (2005) analyzed Japanese verbs that have the meaning of TEAR. Three Japanese verbs, namely saku, chigiru, and yaburu were analyzed using Natural Semantic Metalanguage (NSM) theory. The results showed that these three verbs can be differentiated by their objects, the way to do the activity, and the end result expected from the activity. Another study conducted on Japanese words using NSM is the study on two virtuous emotions in Japanese, namely nasake 'compassion' and jihi 'mercy' by Hasada (2008). She found that nasake and jihi have very complex meaning components and distinguishing features which are clearly expressed after paraphrasing using the MSA theory. The word nasake has seven components of meaning, while jihi has 18 components of meaning.

In this study, four Japanese synonymous verbs GIVE are discussed. These four verbs are ageru, kureru, kizou suru, and kifu suru. By looking at their argument and semantic structures, the proper usage of these four synonymous verbs based on their meaning components can be obtained. Therefore, Japanese learners can benefit the most from this study.

\section{THEORETICAL FRAMEWORK}


This study applied the argument structure theory proposed by Suzuki (2015) and the semantic structure based on the Natural Semantic Metalanguage (NSM) theory proposed by Goddard and Wierzbicka (2014).

\section{A. Argument Structure}

Argument structure is a representation of the number and type of role arguments associated with a particular predicate (Suzuki, 2015). Kroeger (2004) stated that even when an argument is grammatically optional, it may be semantically obligatory. Arguments are nouns born due to the semantic nature of a verb. In other words, the number and role type of noun of a verb is inherent. Based on the arguments that obligatorily accompany a verb, Japanese verbs can be classified into three categories, that is, monovalent verbs, divalent verbs, and trivalent verbs. The four Japanese synonymous verbs GIVE being discussed in this study belong to the trivalent verb category. There are three nouns that accompany these trivalent verbs. The roles of those nouns are agent (dousashu 動作主), beneficiary (juekisha 受益者), and theme (shudai 主題). In Japanese, there are case particles that follow nouns to determine the functions of those nouns in the sentence. The basic sentence structure for verb GIVE in Japanese can be seen as follows (Suzuki, 2015).

$$
\text { noun (1) } \boldsymbol{g} \boldsymbol{a}+\operatorname{noun}(2) \boldsymbol{n i}+\operatorname{noun}(3) \boldsymbol{o}+\mathrm{verb}
$$

The first argument noun (noun (1)) followed by case particle $g a$ is the subject of the sentence. The second argument noun (noun (2) followed by case particle $n i$ is the indirect object of the sentence. The third argument noun (noun (3)) followed by case particle $o$ is the direct object of the sentence. In Japanese, the case particles, besides showing the grammatical relations, also show the semantic roles of the nouns. The ga particle shows the nominative case or the subject playing a role as the agent. The $n i$ particle shows the dative case or the indirect object playing a role as the beneficiary. The $o$ particle shows the accusative case or the direct object playing a role as the theme.

\section{B. Semantic Structure}

Semantic structure is the configuration of the meaning of the word. Semantic structure can be understood due to the grammatical relationship between the verb and the argument owned by the verb (Beratha, 2000). The NSM theory used in this study is a mini-language that is formed by the lexicon and syntax of a natural language. The exponents used in the explication in this mini-language are called semantic primes. Up to now, there are 65 semantic primes that can be used to describe the meaning (Goddard and Wierzbicka, 2014). A list of these 65 exponents is provided in table 1.

TABLE 1

THE LIST OF 65 EXPONENTS OF SEMANTIC PRIMES

\begin{tabular}{ll}
\hline I-ME, YOU, SOMEONE, SOMETHING-THING, PEOPLE, BODY & substantives \\
\hline KIND, PARTS & relational substantive \\
\hline THIS, THE SAME, OTHER-ELSE & determiners \\
\hline ONE, TWO, SOME, ALL, MUCH-MANY, LITTLE-FEW & quantifiers \\
\hline GOOD, BAD & evaluators \\
\hline BIG, SMALL & descriptors \\
\hline KNOW, THINK, WANT, DON'T WANT, FEEL, SEE, HEAR & mental predicates \\
\hline SAY, WORDS, TRUE & speech \\
\hline DO, HAPPEN, MOVE, TOUCH & actions, events, movement, contact \\
\hline BE (SOMEWHERE), THERE IS, BE (SOMEONE)'S, BE (SOMEONE/SOMETHING) & location, existence, possession, specification \\
\hline LIVE, DIE & life and death \\
\hline WHEN-TIME, NOW, BEFORE, AFTER, A LONG TIME, A SHORT TIME, FOR SOME TIME, & time \\
MOMENT & space \\
\hline WHERE-PLACE, HERE, ABOVE, BELOW, FAR, NEAR, SIDE, INSIDE & logical concepts \\
\hline NOT, MAYBE, CAN, BECAUSE, IF & intensifier, augmentor \\
\hline VERY, MORE & similarity \\
\hline LIKE-WAY-AS & \\
\hline
\end{tabular}

\section{METHODOLOGY}

The collected data in this study were taken from Balance Corpus of Contemporary Written Japanese (BCCWJ). This corpus can be accessed at https://chunagon.ninjal.ac.jp. In the BCCWJ corpus, the verb which is being studied is entered in the KWIC (Key Word in Context) search box. KWIC is a format for displaying concordance lines with the words that are the focus of the search lined up in the middle column, while the right and left columns contain words that indicate the context before and after the observed word (Yuliawati, 2018). By entering the verb in the KWIC, the usage of the verb can be described, and the semantic components of each verb can be determined. The example sentences found as data are glossed per morpheme and followed by free translation.

\section{DISCUSSION}

There are at least four verbs that have the equivalent for GIVE in Japanese, namely ageru, kureru, kizou suru, and kifu suru. Although these four verbs are synonymous, they can be differentiated by their argument structures and 
semantic structures. The explication given for each Japanese verb GIVE above is based on their meaning components. The fact that these four verbs are synonymous can be seen from their overlapping meaning components. However, there are also distinctive features that differentiate these four synonymous verbs. Therefore, they cannot completely replace each other in every context. Table 2 below shows the meaning components of these four synonymous verbs.

TABLE 2

The MEANing COMPONEnTs' COMPARISOn AMONG JAPANESE Verbs GIVE

\begin{tabular}{|c|c|c|c|c|c|}
\hline No & Meaning Components & ageru & kureru & Kifu suru & Kizou suru \\
\hline 1 & From people of high to low social positions & $(+)$ & $(-)$ & $(+)$ & $(+)$ \\
\hline 2 & Equal social position / equal & $(+)$ & $(+)$ & $(-)$ & $(-)$ \\
\hline 3 & Speech level & $(-)$ & $(-)$ & $(-)$ & $(-)$ \\
\hline 4 & Formality & $(-)$ & $(-)$ & $(+)$ & $(+)$ \\
\hline 5 & There must be a specific purpose & $(-)$ & $(-)$ & $(+)$ & $(+)$ \\
\hline 6 & Gift in the form of money & $(+)$ & $(+)$ & $(+)$ & $(-)$ \\
\hline 7 & Gift in the form of goods & $(+)$ & $(+)$ & $(+)$ & $(+)$ \\
\hline 8 & Transfer of ownership & $(+)$ & $(+)$ & $(+)$ & $(+)$ \\
\hline
\end{tabular}

\section{A. The Verb Ageru}

Ageru is a trivalent verb that has the basic sentence structure noun (1) $\boldsymbol{g} \boldsymbol{a}+$ noun (2) $\boldsymbol{n i}+$ noun (3) $\boldsymbol{o}+$ verb. [However, based on the data analysis, there is another sentence structure that can be found using the verb ageru. That sentence structure is noun (1) $\boldsymbol{k a r a}+$ noun (2) $\boldsymbol{n i}+$ noun (3) o + verb. The particle accompanying the noun (1) is kara. By using a different particle, the semantic role of noun (1) is changed. Table 2 below shows the semantic roles and types of each noun that function as argument in the verb ageru.

TABLE 3

The Semantic Roles And Types Of Nouns As The Verb AGERU'S ARguments

\begin{tabular}{lll}
\hline $\begin{array}{l}\text { Semantic Roles of the Arguments } \\
\end{array}$ & Particle & Type of Noun \\
\hline $\begin{array}{c}\text { Noun (1) agent } \\
\text { source }\end{array}$ & ga が & animate \\
kara から & animate \\
\hline Noun (2) beneficiary & ni & animate, inanimate \\
\hline Noun (3) theme & $o$ を & concrete, abstract \\
\hline
\end{tabular}

As can be seen in table 3 above, the verb ageru follows the basic sentence pattern of trivalent verbs. The noun which has the case marker particle $\boldsymbol{g} \boldsymbol{a}$ acts as an agent. In addition to the semantic role of an agent, noun (1) can also have a source semantic role with the particle marking of kara. Noun (1) can only be in the form of a living being (animate), for example, occhan 'uncle' and oya 'parent'. The noun (2) which has the case particle marking $\boldsymbol{n i}$ acts as a beneficiary and can be in the form of living things (animate) or non-living objects (inanimate), for example, karera "they" and Amerika "America". Noun (3) that has the case marking particles $\boldsymbol{o}$ acts as theme and can be in the form of concrete or abstract objects, for example, purezento 'gift', esa 'pet food', choko 'chocolate', hyouka 'assessment', and hitotsu no fukai inshou 'a deep impression'.

The following are examples of sentences that can be found in the data.
(1) 親
Oya
加子供
$\begin{array}{ll}\text { に } & \text { お金 } \\ \text { ni } & \text { okane } \\ \text { dat } & \text { money }\end{array}$
をあげるの
o ageru no
に、...
parents
kara kodomo
dat money acc give
nomi
ni, ....
'To give money from parents to children, ....'

Example sentence (1) above shows the semantic role of the ablative which is marked by the particle kara in the form of an animate noun, namely oya 'parent'. The semantic role of beneficiary, which is indicated by the particle case ni is an animate noun, namely kodomo 'children'. Meanwhile, the semantic role of theme, which is indicated by the particle $\boldsymbol{o}$, is a concrete noun, namely okane 'money'.
(2) クッキー は あげない。でも、
Kukkii wa agenai. Demo, arigatou o ageru yo.
cookie top give-neg. but thank you acc give pcl

'(I will) not give (you) cookies. But, give thank you.'

Example sentence (2) shows the semantic roles of agent and beneficiary that undergo a deletion process. Meanwhile, the semantic role of theme is marked with particle $o$ together with an abstract noun, namely arigatou 'thank you'.

The verb ageru is the basic verb to express the meaning of GIVE. Therefore, it contains only five semantic components (a-e) as follows. In Japanese, the role of agent of ageru can be first person, second person, or third person. The role of beneficiary of ageru can be second person or third person (Tanaka et.al, 2018). Based on the usage found for the verb ageru, the semantic structure of ageru can be made as follows.

$\mathrm{X}$-ga Y-ni Z-o ageru ('X gives Z to Y') 
a) someone $\mathrm{X}$ does something to someone else $\mathrm{Y}$

b) before this, something Z was X's

c) $\mathrm{X}$ wants other people $\mathrm{Y}$ to be able to say about $\mathrm{Z}$, "this is mine."

d) something $\mathrm{Z}$ moves from $\mathrm{X}$ to $\mathrm{Y}$

e) X wants this to happen.

\section{B. Kureru}

The verb Kureru is a trivalent verb that has the basic sentence structure noun (1) $\boldsymbol{g} \boldsymbol{a}+$ noun (2) $\boldsymbol{n i}+$ noun (3) $\boldsymbol{o}+\mathrm{verb}$. Based on the data analysis, there is no other sentence structure that can be found using the verb kureru. Table 3 below shows the semantic roles and types of each noun that functions as argument in the verb kureru.

TABLE 4

The Semantic Roles And Types Of Nouns As The Verb KURERU'S ARguments

\begin{tabular}{lll}
\hline Semantic Roles of the Arguments & Particle & Type of Noun \\
& & \\
\hline Noun (1) agent & $g a$ が & animate, inanimate \\
\hline Noun (2) beneficiary & $n i$ に & animate \\
\hline Noun (3) theme & $o$ を & concrete, abstract \\
\hline
\end{tabular}

As can be seen in table 4 above, the verb kureru follows the basic sentence pattern of trivalent verbs. Noun (1) which has the $\boldsymbol{g} \boldsymbol{a}$ case marking particle, acts as agent and can be noun/s in the form of living things (animate) or non-living objects (inanimate), for example, takusan no kata 'many people' and konbini 'mini market'. The noun (2) which has a particle marking $\boldsymbol{n i}$, acts as a beneficiary and can only be a noun in the form of a living being (animate). Observations on the corpus indicate the occurrence of this noun (2) is deleted. This is understandable because the verb kureru 'to give' has selectional restrictions on its beneficiary argument, that is, it can only be in the first person. Nouns that have $\boldsymbol{o}$ case marking particle act as theme and can be nouns in the form of concrete or abstract objects, for example, biniiru-bukuro 'plastic bag', sensu 'fan', okozukai 'pocket money', yuuki 'courage', and chikara 'energy'.

The following are examples of sentences that can be found in the data.

$\begin{array}{llllll}\text { (3) コンビニ } & \text { は } & \text { 袋 } & \text { を } & \text { くれる } & \text { し、... } \\ \text { Konbini } & \text { wa } & \text { fukuro } & \text { o } & \text { kureru } & \text { shi, .... } \\ \text { Mini market } & \text { top } & \text { bag } & \text { acc } & \text { give } & \text { cont .... }\end{array}$

Example sentence (3) shows that the semantic role of agent in the form of an inanimate noun is also a noun that functions as the topic of the sentence, namely mini market. In Japanese, when the topic of the sentence and the subject have the same noun, then the subject is deleted (Suzuki, 2015). The noun that has the semantic role of beneficiary also undergoes a deletion process in this example sentence. Meanwhile, the semantic role of theme which is indicated by the particle case $\boldsymbol{o}$, is a concrete noun, namely bag.

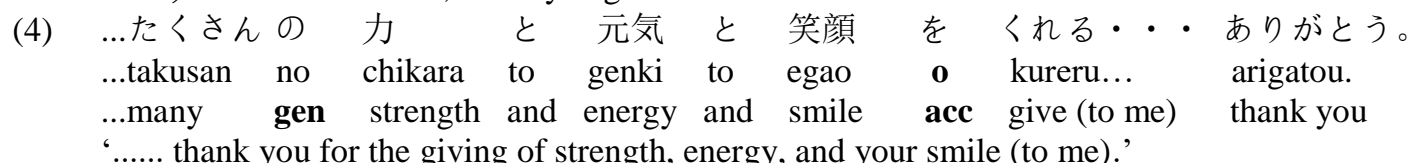

Example sentence (4) shows that the nouns with semantic roles of agent and beneficiary undergo the deletion process. Meanwhile, the semantic role of theme noun which is indicated by the particle $\boldsymbol{o}$, is an abstract noun, namely strength, energy, and smile.

The verb kureru is similar to the verb ageru. It also contains only five semantic components (a-e) as follows. However, the difference is in the noun that can fill the role of beneficiary of kureru. It can be first person while the role of agent can be second person or third person (Tanaka et al., 2018). Based on the usage found for the verb kureru, the semantic structure of kureru can be made as follows.

$\mathrm{X}$-ga Y-ni Z-o kureru ('X gives Z to $\mathrm{Y}^{\prime}$ )

a) someone $X$ doing something to someone else $Y$ (me)

b) before this, something $Z$ was X's

c) X wants other people $\mathrm{Y}(\mathrm{I})$ to be able to say about $\mathrm{Z}$, "this is mine"

d) something $\mathrm{Z}$ moves from $\mathrm{X}$ to $\mathrm{Y}$

e) $\mathrm{X}$ wants this to happen.

\section{Kizou Suru}

The verb kizou suru is a trivalent verb that has the basic sentence structure noun (1) $\boldsymbol{g a}+$ noun (2) $\boldsymbol{n i}+$ noun (3) $\boldsymbol{o}+$ verb. However, based on the data analysis, there are two other sentence structures that can be found using kizou suru. That sentence structure is noun (1) $\boldsymbol{k a r a}+$ noun (2) $\boldsymbol{n i}+$ noun (3) o + verb and noun (1) $\boldsymbol{k a r a}+$ noun (2) $\boldsymbol{e}+$ noun (3) $\boldsymbol{o}+$ verb. The particle accompanying the noun (1) is kara. By using a different particle, the semantic role of noun (1) is changed. In the second new sentence structure, the particle accompanying the noun (2) is $\boldsymbol{e}$. In this new sentence 
structure, the semantic role of noun (2) is also changed. Table 4 below shows the semantic roles and types of each noun that functions as argument in kureru.

TABLE 5

The SEmantic Roles And Types Of Nouns As The Verb KIZOU SURU'S ARGuments

\begin{tabular}{cll}
\hline Semantic Roles of the Arguments & Particle & Type of Noun \\
& & \\
\hline $\begin{array}{c}\text { Noun (1) agent } \\
\text { source }\end{array}$ & ga が & $\begin{array}{l}\text { animate, inanimate } \\
\text { animate }\end{array}$ \\
\hline $\begin{array}{c}\text { Noun (2) beneficiary } \\
\text { goal }\end{array}$ & $n i$ a & $\begin{array}{l}\text { animate, inanimate } \\
\text { inanimate }\end{array}$ \\
\hline Noun (3) theme & $o$ を & concrete \\
\hline
\end{tabular}

As can be seen in table 5 above, the verb kizou suru follows the basic sentence pattern of trivalent verbs. The noun (1) which has the case marker particle ga , acts as an agent and can be nouns in the form of living things (animate) or nonliving objects (inanimate). Apart from that, the particle marking for noun (1) can also be kara with an animate noun filler, which acts as the source. Nouns that have particles marking this case, act as beneficiary and can be nouns in the form of living things (animate) or non-living objects (inanimate). In addition, the particle marking for the noun (2) can also be the particle $e$ with the inanimate noun filler which acts as a goal. Nouns that have case marking particles $\boldsymbol{o}$, act as themes and can only be concrete nouns such as kichou na shiryou 'precious material', sharin hitokumi 'a pair of wheels', and tochi 'earth'.

The following are examples of sentences that can be found in the data.
(5) 本庄小学校
Honjō shōgakkō
$\begin{array}{lll}\boldsymbol{e} & \text { 図書 (五十万円分) を } \\ \text { tosho (go juu man-en bun) } & \text { o }\end{array}$
寄贈。
acc give
'Giving books ( $¥ 500.000$ ) to Honjo elementary school.'

Example sentence (5) shows that the noun with a semantic role of agent has been deleted. The noun which has the role of semantic role of goal marked by particle $\boldsymbol{e}$ is an inanimate noun, namely Honjo Elementary School. Meanwhile, the noun with semantic role of theme marked with particle $\boldsymbol{o}$ is a concrete noun, namely a book.

(6) 茅野市
Chinoshi no kata kara sharin hitokumi o kizo shite itadakimashita
Chino city gen person abl a pair of wheels acc give receive-pst
'One person from the city of Chino donated a pair of wheels.'

The example sentence (6) shows that the noun (1) is an animate noun, that is, the word 'person' is marked by the particle kara and acts as the source. The noun (2) is deleted. Meanwhile, the noun with semantic role of theme marked with particle case $\boldsymbol{o}$ is a concrete noun, namely sharin hitokumi 'a pair of wheels'.

The verb kizou suru has three additional meaning components (f-h) compared to ageru and kureru verbs. The role of theme can only be a physical object (excluding money). The agent role is a person that has higher social status than the beneficiary role (meaning component g). Therefore, the verb kizou suru is chosen (meaning component h). Based on the usage found for the verb kizou suru, the semantic structure of kizou suru can be made as follows.

$\mathrm{X}$-ga Y-ni Z-o kizou suru ('X gives Z to Y')

a) someone $\mathrm{X}$ does something to someone else $\mathrm{Y}$

b) before this, something $Z$ [physical thing excluding money] was $X$ 's

c) $\mathrm{X}$ wants other people $\mathrm{Y}$ to be able to say about $\mathrm{Z}$, "this is mine"

d) something $\mathrm{Z}$ moves from $\mathrm{X}$ to $\mathrm{Y}$

e) $\mathrm{X}$ wants this to happen.

f) this happens because someone $\mathrm{X}$ is thinking about something

g) $\mathrm{X}$ is not someone like $\mathrm{Y}, \mathrm{Y}$ cannot think of anything bad about $\mathrm{X}$

h) X says this way not any other way

\section{Kifu Suru}

The verb kifu suru is a trivalent verb that has the basic sentence structure noun (1) $\boldsymbol{g a}+$ noun (2) $\boldsymbol{n i}+$ noun (3) $\boldsymbol{o}+$ verb. Based on the data analysis, there is no other sentence structure that can be found using the verb kifu suru. Table 5 below shows the semantic roles and types of each noun that functions as argument in the verb kifu suru. 
TABLE 6

The Semantic Roles And Types Of Nouns As The Verb KIFU SURU'S ARGUMENTS

\begin{tabular}{|c|c|c|}
\hline Semantic Roles of the Arguments & Particle & Type of Noun \\
\hline Noun (1) agent & gaが & animate \\
\hline Noun (2) beneficiary & $n i$ に & animate \\
\hline Noun (3) theme & $o$ を & concrete \\
\hline
\end{tabular}

As can be seen in table 6 above, the verb kifu suru follows the basic sentence pattern of trivalent verbs. The noun (1) which has the case marker particle $g a$, acts as an agent and is a noun in the form of a living being (animate). The noun (2) which has a particle marking $\boldsymbol{n i}$, acts as a beneficiary and is also a noun in the form of a living being (animate). The noun (3) which has the case marking particle $\boldsymbol{o}$, acts as a theme and can only be nouns in the form of concrete objects, for example, okane 'money', anko 'bean paste', ango fuku 'clothes (coat) Ango', and gojuu man doru '500 thousand dollars '.

The following are examples of sentences that can be found in the data.

$\begin{array}{llllllll}\text { (8) 初午の日 (二月) } & \text { に } & \text { は } & \text { お稲荷さん } & \text { 餡こ } & \text { を } & \text { 寄附して。 } \\ \text { Hatsuma no hi (2gatsu) } & n i & \text { wa } & \text { oinarisan } & \text { ni } & \text { anko } & \text { o } & \text { kifu shite }\end{array}$

"first horse day" (February) pada top Inari god dat bean paste acc give-cont

'On "first horse day" (February), giving bean paste to god Inari (god of harvest)'

Example sentence (8) shows that the noun with semantic role of agent was deleted. The semantic role of beneficiary which is indicated by particle $\boldsymbol{n i}$ is an animate noun, namely oinarisan 'Inari God'. Meanwhile, the noun with the semantic role of theme marked with particle $\boldsymbol{o}$ is a concrete noun, namely anko 'bean paste'.

$\begin{array}{lllllll}\text { (9) 僕 } & \text { が } & \text { 一 } & \text { 安吾服 } & \text { を } & \text { 寄附する } & \text { よ。 } \\ \text { Boku } & \text { ga } & \text { hitotsu } & \text { Ango fuku } & \text { o } & \text { kifu suru } & \text { yo. } \\ \text { I } & \text { nom one } & \text { Ango coat } & \text { acc } & \text { give } & \text { pcl } \\ \text { 'I will give you one Ango coat.' } & & & \end{array}$

Example sentence (9) shows the noun with the semantic role of agent is indicated by the particle ga together with a singular first-person pronoun, namely boku 'I'. The noun with the semantic role of beneficiary has undergone a deletion process. Meanwhile, the noun with the semantic role of theme marked by particle case $\boldsymbol{o}$ is a concrete noun, namely Ango coat.

The verb kifu suru has similar meaning component with kizou suru. However, the difference is in the thing that has the role of theme. While the role of theme in kizou suru verb cannot be a physical thing such as money, the kifu suru can take any kind of physical things including money as its theme. Based on the usage found for the verb kifu suru, the semantic structure of kifu suru can be made as follows.

$\mathrm{X}$-ga Y-ni Z-o kifu suru ('X gives Z to $\mathrm{Y}^{\prime}$ )

a) someone $X$ does something to someone else $Y$

b) before this, something Z [physical thing including money] was X's

c) $\mathrm{X}$ wants other people $\mathrm{Y}$ to be able to say about $\mathrm{Z}$, "this is mine"

d) something $\mathrm{Z}$ moves from $\mathrm{X}$ to $\mathrm{Y}$

e) X wants this to happen.

f) this happens because someone $X$ is thinking about something

g) X is not someone like $\mathrm{Y}, \mathrm{Y}$ cannot think of anything bad about $\mathrm{X}$

h) X says this way not any other way

\section{CONCLUSION}

By applying argument structure theory and NSM theory in the analysis of four Japanese synonymous verbs in this study, distinctive meaning components of these four Japanese verbs can be alerted. Although there are some overlapping meaning components, the existence of these distinctive meaning components causes these synonymous verbs not to be able to fully replace each other in all contexts. Therefore, Japanese learners should carefully decide their word of choice to express their intended meaning.

\section{APPENDIX. ABBREVIATION}

$\begin{array}{ll}\text { abl } & \text { ablative (source) } \\ \text { acc } & \text { accusative case } \\ \text { cont } & \text { continuative } \\ \text { dat } & \text { dative case } \\ \text { neg } & \text { negative } \\ \text { nom } & \text { nominative case } \\ \text { nomi } & \text { nominalizer }\end{array}$




$\begin{array}{ll}\text { pcl } & \text { particle } \\ \text { pst } & \text { past } \\ \text { purp } & \text { purposive } \\ \text { top } & \text { topic }\end{array}$

\section{ACKNOWLEDGMENTS}

The authors wish to thank those who have contributed to this research, especially lecturers in the linguistic doctoral postgraduate program at Udayana University. This work was supported partly by funding from the Ministry of Higher Education in Indonesia (no.64553/A2.1/KP/2018).

\section{REFERENCES}

[1] Beratha, N.L.S. (2000). Struktur dan Peran Semantis Verba Ujaran Bahasa Bali. In B.K. Purwo (ed.). Kajian Serba Linguistik: Untuk Anton Moeliono Pereksa Bahasa. Jakarta: PT BPK Gunung Mulia, 287-294.

[2] Goddard, C. \& A. Wierzbicka. (2014). Words and Meaning: Lexical Semantics across domains, languages, and cultures. New York: Oxford University Press.

[3] Gumbira, N. R. (2013). Analisis Makna Verba Omou dan Kangaeru Sebagai Sinonim. Universitas Pendidikan Indonesia. repository.upi.edu

[4] Hasada, R. (2008). Two "Virtous Emotions" in Japanese: Nasake/Joo and Jihi. in C. Goddard (ed.). Cross-Linguistic Semantics. (pp. 331-347). Philadelpia: John Benjamins Publishing.

[5] Horie, K. (2018). Linguistic Typology and the Japanese Language. In Y. Hasegawa (ed.). The Cambridge Handbook of Japanese Linguistics. Berkeley: University of Califormia, 65-86.

[6] Japan Foundation. (2019). Japanese language education in 142 countries / regions, the largest number ever 2018 "Overseas Japanese Language Education Institution Survey" Results. https://www.jpf.go.jp/j/about/press/2019/029.html (accessed on 7 September 2020).

[7] Kroeger, P. R. (2004). Analysing Syntax: A Lexical-Functional Approach. Cambridge: Cambridge University Press.

[8] Otomo, A. \& A. Torii. (2005). An NSM Approach the meaning of tear and Its Japanese Equivalents. in Conference of the Australian Linguistics Society. www.als.asn.au/proceedings/als2005/otomo-torii.pdf (accessed on 18 April 2018).

[9] Shiba, T. H. \& Cho K. J. (2017). Koopasu ni Motozuita Ruigigo Bunseki - "Miotosu", "Misugosu", "Minogasu" wo rei ni -. [in Japanese] https://ci.nii.ac.jp/naid/120006010658 (accessed on 17 April 2018).

[10] Suzuki, T. (2015). Nihongo Bunpo Fairu: Nihongogaku to Gengogaku kara no Apuroochi. Tokyo: Kuroshio Shuppan

[11] Tanaka, Y., S. Sawada, A. Shigekawa, A. Makino, K. Mokogami. (2018). Minna no Nihongo I. Surabaya: Lincip Publishing.

[12] Yuliawati, S. (2018). Kajian Linguistik Korpus dan Semiotik: Perempuan Sunda dalam Kata. Bandung: Refika Aditama.

[13] Zarifa, R. N., Herniwati, \& Sutjiati N. (2017). Analisis Kesalahan Penggunaan Adjektiva Taisetsu na, Daiji na, dan Juuyou na. dalam EduJapan Journal vol.1, No.1, pp. 6-18. http://ejournal.upi.edu/index.php/edujapan/article/view/7550/0 (accessed on 10 April 2018).

I Gede Oeinada is currently a doctoral student studying at Udayana University, Bali, Indonesia. He accomplished his Magister program in 2009 from Udayana University, majoring in linguistics. His interest is in semantics, translations, and Japanese linguistics.

Ni Luh Sutjiati Beratha is a professor in semantics at Udayana University, Bali, Indonesia. She accomplished her Magister program at the Department of Linguistics, Monash University Melbourne Australia in 1989, and a Ph.D. degree from the Australian National University (ANU) Canberra Australia in 1992. She has published many books, dictionaries, and other publications.

I Nengah Sudipa is a professor in linguistics at Udayana University, Bali, Indonesia. He accomplished his Magister program in Linguistic Department, Monash University Melbourne Australia. He graduated from the doctoral program of Linguistics at Udayana University. His research interest is semantics and psycholinguistics, and he has published many various books.

Made Sri Satyawati is an associate professor at Udayana University, Bali, Indonesia. She accomplished her Magister program in Linguistics from Padjadjaran University, Bandung, Indonesia, in 1999 and obtained her Doctorate Degree in Linguistics from Udayana University in 2010. Her research interest is linguistics, namely syntax, morphology, and semantics. 